\title{
EFFECT OF MARKETING CHANNEL ON MARKET PERFORMANCE OF WARE YAM IN ABIA STATE, NIGERIA
}

\author{
BY \\ Onyenobi, V.O., Ewuziem, J.E. and Mazza, Mary-Ann \\ National Root Crops Research Institute PMB 7006 Umuahia, Abia State, Nigeria \\ Email:onyenobivincent@yahoo.co.uk
}

\begin{abstract}
The study on marketing channel to determine market performance for ware yam (yam tuber $\geq 1.0$ $\mathrm{kg}$ ) Dioscorea spp was conducted in Abia State, Nigeria. Both purposive and random sampling techniques were used to collect the data used to assess the marketing channel in terms of its structural framework, marketing margin and mark-up policy of traders. The Allen's (1959) simple ordinary least squares (OLS) linear regression model was used to determine the mark-up policies of the traders in the study area. The results of the study showed that the marketing channel is semi-decentralized with socio-economic significance for efficient transfer of product from the farm to the consumer. The marketing margins between the different marketing levels are positively related, and the traders use both the fixed and percentage margin policies to determine the selling price of their product, to reflect the utility created in the product, in order to maximize consumer satisfaction and farmer share relative to marketing share of consumer expenditure on the product. The marketing margins and mark-up policies of the traders are significantly related based on the measure of fitness of the market prices $R^{2}$ 's at the $F_{0.01}$ level. The results of the study have implications for sustainable increases in the levels of employment, output, consumption, better income distribution and poverty reduction in the study area.

Key words: Yam tuber, ware yam, mark up, marketing margin.

http://dx.doi.org/10.4314/jafs.v9i2.3
\end{abstract}

\section{Introduction}

Yam (Discorea spp) is an important tuber crop in Nigeria, where it is produced both as a food and cash crop. Annual production of yam in the country is estimated at 36,720 million tonnes (FAO 2006). Yam is also a socio cultural crop. In 1997 alone, Nigeria accounted for $75 \%$ of world production (Manyong et al. 2001). The annual growth rate for the same period was $6 \%$ for the yield and $10 \%$ for the area planted. Although Nigeria is the largest producer of yam in the world, the need arises for increasing production to satisfy domestic and export demand for yams. The major yam growing areas of Nigeria extend from the rain forest zone to the southern limit of the northern Guinea savanna. Available information on yam marketing in Nigeria includes studies conducted in southeastern Nigeria (Eluagu et al. 1990, Aniebunwa, 2002 and Asumugha et al. 2007). Eluagu et al. described the yam marketing channel as long, consisting of the farmers, agents/wholesalers, wholesaler-retailers, itinerant assemblers, and retailers and consumers. In this case, the wholesaler-retailer controlled $75 \%$ of the yams flowing through the yam marketing channel. According to the authors, the flow of yam trade was in the north-south direction. A structural analysis of yam trade flow into Abia State using total value of purchases as an index of measurement of the market share was conducted in Abia State in Eastern Nigeria (Anuebunwa Journal of the Faculty of Agriculture and Veterinary Medicine, Imo State University, Owerri www.ajol.info 
2002). According to the result, the northern states of Nigeria contributed $67.97 \%$ of all yams supplied to Abia State while the southern states contributed $32.03 \%$, of which Abia accounted for 2.7\%. Correct decision making and planning in trade also depend on reliable information on market conditions (Shepherd 2000). Asumugha et al. (2007) analyzed the marketing channels and efficiency of the marketing system for yams in Nigeria. The result showed that the marketing system of yam in Nigeria is less competitive and therefore less efficient.

The type and complexity of marketing channel may vary for different commodities, depending on the nature (perishability and level of processing), use and value of the commodity, and may influence the marketing margin and mark-up policy of traders in the marketing system. The marketing channel also called a trade channel or distribution channel (Kotler, 1997) is simply the path of a commodity from its raw form to the finished form or the path of a product as it moves from the producer to the final consumer (Olukosi and Isitor, 1990). A marketing channel always includes both the producer and final consumer of the product, as well as all the middlemen involved in the title transfer of the product from the producer to the final consumer.

In agricultural and products marketing, the marketing channel is either centralized or decentralized. A centralized marketing channel is one in which commodities are assembled in large central or terminal markets where they are purchased by wholesalers or processors from farmers' agents (Adekanye and Olayide, 1988) and later sold to the final consumer through the retailer. On the other hand, a decentralized marketing channel does not have such large assembling marketing facilities and traders buy directly from farmers (Adekanye and Olayide, 1988) and later sell to the final consumers. The present study is directed at the analysis of the marketing channel for ware yam (yam tuber $\geq 1.0 \mathrm{~kg}$ ) Dioscrorea spp in the study area, Abia State, Nigeria. Yam in Nigeria is becoming expensive and relatively unaffordable in urban areas as production has not kept pace with population growth leading to demand exceeding supply (Kushwaha and Polycarp 2001). Although yam production in Nigeria is quite high (Nigeria is known to be the largest producer of yam in the world), there is still a need for increased production of yam to satisfy domestic and possibly export demand. If the efficiency of the marketing system for yam is to be improved so as to facilitate its contribution to increased marketing and export, there is the need for better understanding of the marketing channels, the yam marketing margins and the mark up policies to ensure efficient marketing of the crop. In Abia state, Yam has socio-economic importance in the area as a status symbol for men and as a source of food, industrial raw material, employment and income to farmers and yam marketing intermediaries. The marketing system which affects the prices received by the farmers and those paid by buyers, has a profound impact on food security (Asumugha et al 2009).

\section{Objectives of the Study}

The broad objective of the study is to analyze the effect of marketing channel on market performance of ware yam in the study area. The specific objectives includes to:

1. describe the framework of the marketing channel for ware yam in the study area

2. evaluate the marketing margins on ware yam between the marketing levels in the study area

Journal of the Faculty of Agriculture and Veterinary Medicine, Imo State University, Owerri www.ajol.info 
3. determine the mark-up policy of the traders in arriving at the selling prices of ware yam in the study area.

The hypothesis that: there are no significant relationships between the marking margin and markup policy of the traders in the study area was tested. The study is justified because in the study area agriculture is the primary occupation (Nigerian National Bureau of Statistics, 2006).

\section{Research Methodology}

The study was conducted in Abia State, in the south-eastern agro-ecological zone of Nigeria. The state has a population of 2,845,380 inhabitants from 17 local government areas (LGA's) and occupies a land mass of 4,900 $\mathrm{km}^{2}$ (National Bureau of Statistics, 2006). It has a tropical location of latitude $5^{\mathrm{O}} 6^{1} \mathrm{~N}-5^{\mathrm{O}} 24^{1} \mathrm{~N}$ of the Equator and longitude $7^{\mathrm{O}} 18^{1} \mathrm{E}-7^{\mathrm{O}} 54^{1} \mathrm{E}$ of the Greenwich with a mean annual rainfall of $3032 \mathrm{~mm}$ and ferralitic (acid) soil and forest growth vegetation zone (Agboola, 1979).

Field survey data arising from purposive and random sampling techniques were used to achieve the objectives of the study. Six (6) local government areas (LGA's) were purposively selected from the 17 LGA's in Abia State based on the significance of each LGA in the production and marketing of yam in the state. From the selected LGA's, one (1) market was purposively selected from each LGA. Primary non-experimental, cross sectional random market data were generated for the study using questionnaire and oral market interviews. A list of all registered yam traders was collected from the yam traders association of the market. This list formed the sample frame from which a random sample 12 traders was carried out in each market. This was done on weekly basis over a period of one year to generate data used for the study. The resulting random market data were used to analyze the objective of the study.

Appropriate statistical and econometric techniques were used to analyze the data collected from the study. Descriptive statistics involving a simple figure was used to describe the structural framework of the marketing channel, while tables were used to describe the marketing margins between the different marketing levels. Simple ordinary least squares (OLS) linear price regression model was used to determine the mark-up policy of the traders, in the analysis of the marketing margins between the different marketing levels. The model is specified as follows:

$\mathrm{S}_{\mathrm{it}}=\mathrm{a}+\mathrm{bkj}+\mathrm{u}_{\mathrm{i}}$

\section{Where:}

$S_{i t}=$ Monthly selling price of ware yam in one market $i=1,2, \ldots, n$.

$\mathrm{K}_{\mathrm{jt}}=$ Monthly supply price of ware yam in any one market $\mathrm{j}=1,2, \ldots, \mathrm{n}$.

$\mathrm{U}_{\mathrm{i}}=$ Error term

The applied forms of the price regression model used in the study are as follows;

$\hat{\mathrm{W}}_{\mathrm{t}}=\hat{\mathrm{a}}_{\mathrm{o}}+\mathrm{b}_{\mathrm{o}} \mathrm{C}_{\mathrm{ijt}}+\hat{\mathrm{e}}_{\mathrm{i}}$

$\hat{\mathrm{Y}}_{1 \mathrm{i}}=\hat{\mathrm{a}}_{\mathrm{i}}+\hat{b}_{\mathrm{i}} \mathrm{W}_{\mathrm{jt}}+\hat{\mathrm{e}}_{1 \mathrm{i}}$

$\hat{\mathrm{Y}}_{2 \mathrm{t}}=\hat{\mathrm{a}}_{2}+\mathrm{b}_{2} \mathrm{C}_{\mathrm{ijt}}+\hat{\mathrm{e}}_{2 \mathrm{i}}$

Journal of the Faculty of Agriculture and Veterinary Medicine, Imo State University, Owerri www.ajol.info 


\section{Where:}

$\mathrm{W}_{\mathrm{t}}=$ Estimated monthly wholesale (selling) price $\left(\square / \mathrm{kg}^{-1}\right)$ of ware yam in partial trade $\wedge$ relationships (equation 2 ) between the wholesalers in one market

$\mathrm{i}=1,2, \ldots 6$ and farmers in any one market

$\mathrm{j}=1,2, \ldots 6$ farmers in the study area.

$\hat{\mathrm{Y}}_{\mathrm{it}}=$ Estimated monthly retail (selling) price $\left(\square / \mathrm{kg}^{-1}\right)$ of ware yam in partial trade relationships (equation 3 ) between the retailers in one market

$I=1,2 \ldots 6$, and wholesalers in any market $\mathrm{j}=1,2, \ldots 6$

$\mathrm{Y}_{2 \mathrm{t}}=$ Estimated monthly retail (selling) price $\left(\square \mathrm{kg}^{-1}\right.$ ) of ware yam in partial trade relationships

$\wedge$ (equation 4 ) between the retailers one market.

$\mathrm{i}=1,2 \ldots 6$, and wholesalers in any market $\mathrm{j}=1,2, \ldots 6$.

$\mathrm{G}_{\mathrm{jt}}=$ Monthly farm gate (supply) price $\left(\square^{\mathrm{kg}-} 1\right)$ of ware yam in any market

$\mathrm{j}=1,2, \ldots 6$, in the partial trade relationships between the wholesalers and farmers (equation 4 ).

$\mathrm{W}_{\mathrm{jt}}=$ Monthly wholesale (supply) price $\left(\square \mathrm{kg}^{-1}\right)$ of ware yam in any market $\mathrm{j}=1,2, \ldots 6$, in partial trade relationships between the retailers and wholesalers (equation 3).

$\hat{a}, b, \hat{e}_{i}=$ Regression intercept, coefficient, and error term, respectively, in the estimated partial $\wedge$ trade relationships.

The mark-up policies of the traders were distinguished as fixed, semi-fixed, or percentage margins, based on the Allen (1959) price regression model. Allen (1956) employed this model in the determination of the mark-up policy of retailers in the empirical investigations on retails margins in wholesale-retail trade with reference to fruits and vegetables. The mark-up policies of the traders were distinguished as fixed, semi-fixed, or a percentage margin by comparing the values of the estimated regression intercepts â's and the estimated regression coefficient b's, accordingly,

i. Where â had a value of 0.0 or virtually so, a percentage margin was indicated;

ii. Where $\hat{b}=1.0$ or virtually so, a fixed margin was indicated;

iii. Where $\mathbb{b}$ was less than one third of $\hat{a}$ or $\wedge$ was negative and $\hat{a}$ was positive, then a fixed margin was assumed;

iv. Wherê $\mathrm{b}$ was between â third to twice of $\mathrm{a}$, a semi-fixed margin was assumed; and

v. Where â was negative or $\wedge$ was more than twice of $\hat{a}$, a tendency to a percentage margin was indicated.

The mark-up policies of the traders were further estimated using the coefficients of determination $\mathrm{R}^{2}$ 's of the applied forms of the price regression model. The $\mathrm{R}^{2}$, s were tested for significance at the $\mathrm{F}_{0.01}$ level. 


\section{Results and Discussion}

Fig. 1 show the sequence of intermediaries or paths through which the traded ware yam passes from the farmer to consumer in the marketing system. The type and complexity of marketing channel for foodstuff vary with different commodities.

\section{Structural Framework of the Marketing Channel}

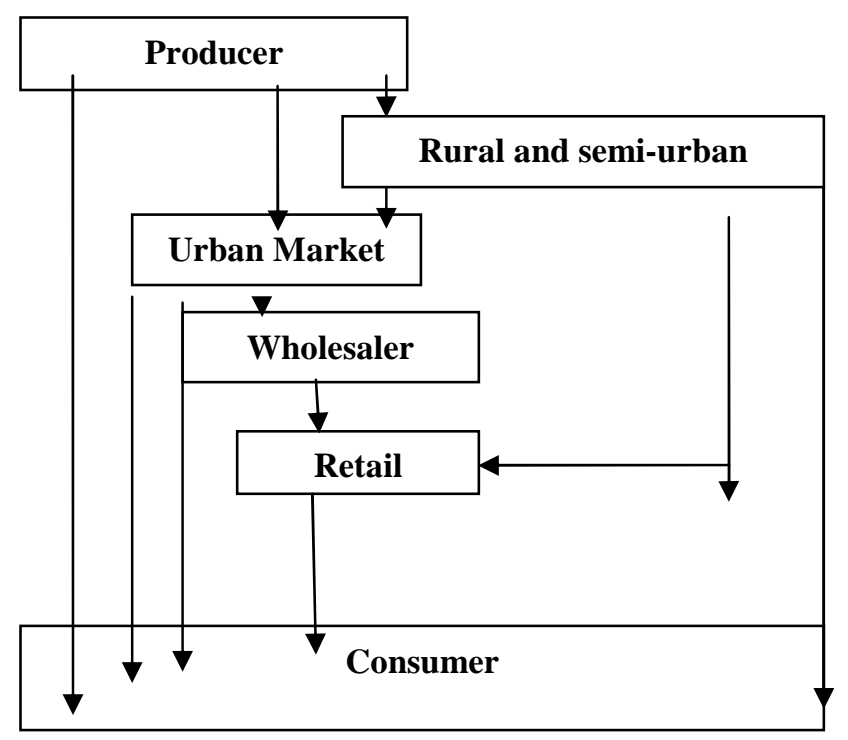

\section{Figure 1; Semi-Decentralized Channel of Distribution of Ware Yam in Abia State}

The marketing channel for ware yam in the study area is better described as semi-decentralized because it is devoid of marketing agents, when compared with the decentralized marketing channel for consumer products (Stanton, 1983) and the centralized marketing channel for foodstuff in Nigeria (Hay, 1975). The semi-decentralized marketing channel for ware yam in the study area is characterized by freedom of entry in the market, efficient market information, and wholesalers and big retailers who readily penetrate the rural farm gate market in response to the profitable market opportunities in order to maximize consumer satisfaction and farmer share relative to the marketing share per unit of the consumer expenditure on ware yam.

As a result, the producers usually sell their wares in the rural, semi-urban and urban markets without recourse to agents. In the rural and semi-urban markets, the producers usually sell in bulk at farm gate price to the wholesalers, retailers and big consumers. But in the urban markets, the producers also sell in bulk at wholesale price directly to big consumers or in small quantities to small consumers through sequence of wholesalers and retailers in the marketing channel. The wholesalers on the other hand buy in bulk from the producers and sell directly to the fairly big consumers or indirectly to the small consumers through the retailers in the marketing channel. The retailers are the final link between the farmers and consumers, and usually buy in bulk from the producers and/or the wholesalers, and sell in much smaller quantities to the consumer in the study area. 


\section{Marketing Margins on Ware Yam}

Tables 1, 2, and 3 show the marketing margins on ware yam as it moves from the farm to the final consumer. The mean monthly marketing margins on ware yam represent the differences between the prices paid and received (Reddy et al 2006) by the traders. This also reflects all the varying handling costs and profit (Ejiga 1977), including efficiency of each channel in the marketing system.

Table 1: Mean Monthly Farm gate Wholesale Margin on Ware Yam in the Study Area.

\begin{tabular}{lllll}
\hline Market & $\begin{array}{l}\text { Mean Monthly } \\
\text { Farmgate } \\
\text { (Supply) Price }\end{array}$ & $\begin{array}{l}\text { Mean Monthly } \\
\text { Wholesale } \\
\text { (Selling) Price }\end{array}$ & $\begin{array}{l}\text { Mean Monthly } \\
\text { Absolute Value }\end{array}$ & $\begin{array}{l}\text { Marketing Margin } \\
\text { Percentage Value }\end{array}$ \\
\hline & $\mathbf{N k g}^{-1}$ & $\mathbf{N k g}^{-1}$ & $\mathbf{N k g}^{-1}$ & $\mathbf{\%}$ \\
Eke Agbagwu & 32.41 & 38.10 & 5.69 & 14.93 \\
Orie Amaoji & 32.23 & 38.19 & 5.96 & 15.61 \\
Nkwo Ndoro & 32.29 & 38.25 & 6.66 & 15.58 \\
Ogwumabiri Ibeku & 32.53 & 39.17 & 6.64 & 16.95 \\
Ariaria Market & 32.45 & 38.87 & 6.42 & 16.52 \\
Umungasi Market & 32.38 & 38.70 & 6.32 & 16.33 \\
Mean & $\mathbf{3 2 . 3 8}$ & $\mathbf{3 8 . 5 5}$ & $\mathbf{6 . 1 7}$ & $\mathbf{1 6 . 0 0}$ \\
\hline
\end{tabular}

Source: Field Survey, 2010

Table 2: Mean Monthly Farm gate Retail Margin on Ware Yam in the Study Area.

\begin{tabular}{llllll}
\hline \multicolumn{1}{c}{ Market } & $\begin{array}{l}\text { Mean Monthly } \\
\text { Farmgate } \\
\text { (Supply) Price }\end{array}$ & $\begin{array}{l}\text { Mean } \\
\text { Retail } \\
\text { Price }\end{array}$ & $\begin{array}{l}\text { Monthly } \\
\text { (Selling) }\end{array}$ & $\begin{array}{l}\text { Mean Monthly } \\
\text { Absolute } \\
\text { Value }\end{array}$ & $\begin{array}{l}\text { Marketing Margin } \\
\text { Percentage } \\
\text { Value }\end{array}$ \\
\hline & $\mathbf{N k g}^{-1}$ & $\mathbf{N k g}^{-1}$ & $\mathbf{N k g}^{-1}$ & \% \\
Eke Agbagwu & 32.41 & 43.21 & 10.80 & 24.99 \\
Orie Amaoji & 32.23 & 43.21 & 10.98 & 25.41 \\
Nkwo Ndoro & 32.29 & 43.78 & 11.49 & 26.25 \\
Ogwumabiri Ibeku & 32.53 & 43.57 & 11.04 & 25.34 \\
Ariaria Market & 32.45 & 43.48 & 11.03 & 25.37 \\
Umungasi Market & 32.38 & 43.49 & 11.11 & 25.56 \\
Mean & 32.38 & 43.46 & 11.08 & 25.49 \\
\hline
\end{tabular}

Source: Field Survey, 2010

Journal of the Faculty of Agriculture and Veterinary Medicine, Imo State University, Owerri www.ajol.info 
Table 3: Mean Monthly Wholesale / Retail Margin on Ware Yam in the Study Area.

\begin{tabular}{llllll}
\hline \multicolumn{1}{c}{ Market } & $\begin{array}{l}\text { Mean Monthly } \\
\text { Wholesale } \\
\text { (Supply) Price }\end{array}$ & $\begin{array}{l}\text { Mean } \\
\text { Retail } \\
\text { Price }\end{array}$ & $\begin{array}{l}\text { Monthly } \\
\text { (Selling) }\end{array}$ & $\begin{array}{l}\text { Mean Monthly } \\
\text { Absolute } \\
\text { Value }\end{array}$ & $\begin{array}{l}\text { Marketing Margin } \\
\text { Percentage } \\
\text { Value }\end{array}$ \\
\hline & $\mathbf{N k g}^{-1}$ & $\mathbf{N k g}^{-1}$ & $\mathbf{N k g}^{-1}$ & \% \\
Eke Agbagwu & 38.10 & 43.21 & 5.11 & 11.83 \\
Orie Amaoji & 38.19 & 43.21 & 5.02 & 11.62 \\
Nkwo Ndoro & 38.25 & 43.78 & 5.53 & 12.63 \\
Ogwumabiri Ibeku & 39.17 & 43.57 & 4.40 & 10.10 \\
Ariaria Market & 38.87 & 43.48 & 4.61 & 10.60 \\
Umungasi Market & 38.70 & 43.49 & 4.79 & 11.01 \\
Mean & 38.55 & 43.46 & 4.91 & 11.30 \\
\hline
\end{tabular}

\section{Source: Field Survey, 2010}

The mean monthly farm gate retail marketing margin of $25.49 \%$ (Table 2 ) is relatively higher than the mean monthly farm gate-wholesale marketing margin of $16 \%$ (Table 1) and the wholesale- retail marketing margin of $11.30 \%$ (Table 3), because of the increased number and cost of the utility-creating marketing functions (Coman and Young, 1993; Olukosi and Isitor, 1990; Kohls and Uhl, 1990; Downey and Erickson, 1981) performed by retailers in the farm gate retail marketing channel (Fig. 1). This implies that retailers reduce their marketing cost and make more profit from each unit of commodity relative to cost (Iheke and Obasi 2009). The effect of no government regulation on the demand and supply of ware yam in the study area has implication for competitive mark-up policy and marketing efficiency of the traders.

\section{Mark-up Policy on Ware Yam}

The estimated simple OLS linear price regressions and mark-up policies on ware yam in the study area are highlighted in Tables 4, 5 and 6, based on the Allen (1959) price regression model. The slope or regression coefficient represents the sellers' markup policy which is the rate by which the mean monthly selling price increases when the supply price increases by $\square 1.00 \mathrm{~kg}^{-1}$.

Table 4: Estimated Simple OLS Linear Partial Regression and Partial Mark-up Policy of the Ware Yam Wholesalers in the Farm Gate Wholesale Marketing Channel in the Study Area.

\begin{tabular}{lcccc}
\multirow{2}{*}{ Market Channels } & \multicolumn{3}{c}{ Priçe Regression $\hat{\mathbf{W}}_{\hat{\mathbf{e}}}=\hat{\mathbf{a}}_{\mathbf{0}}+\mathbf{b}_{\mathbf{0}} \mathbf{G}_{\mathbf{j t}}+\hat{\mathbf{e}}_{\mathbf{o}}$} \\
\cline { 2 - 5 } & $\hat{\mathbf{a}}_{\mathbf{o}}$ & $\mathbf{b}_{\mathbf{o}}$ & \multicolumn{1}{c}{$\mathbf{R}^{\mathbf{2}}$} & \multicolumn{1}{c}{$\mathbf{F}$} \\
\hline Eke Agbagwu Vs Eke Agbagwu & 6.895 & .670 & .932 & 132.020 \\
Eke Agbagwu Vs Orie Amaoji & -5.541 & 1.354 & .914 & 106.566 \\
Eke Agbagwu Vs Nkwo Ndoro & -7.821 & 1.423 & .908 & 98.231 \\
Eke Agbagwu Vs Ogwumabiri Ibeku & -7.711 & 1.411 & .898 & 87.624 \\
Eke Agbagwu Vs Ariaria Market & -8615 & 1.440 & .945 & 172.083 \\
Orie Amaoji Vs Umugasi Market & -8575 & 1.441 & .939 & 154.589
\end{tabular}

Journal of the Faculty of Agriculture and Veterinary Medicine, Imo State University, Owerri www.ajol.info 
Orie Amaoji Vs Orie Amaoji

$\begin{array}{llll}6.475 & .674 & .876 & 71.015 \\ -5.884 & 1.365 & .870 & 66.900 \\ -5.667 & 1.3459 & .854 & 58.366 \\ -6.579 & 1.380 & .903 & 93.286 \\ -6.601 & 1.383 & .900 & 90.021 \\ 8.048 & .634 & .895 & 84.851 \\ -7.239 & 1.399 & .883 & 75.515 \\ -8.162 & 1.430 & .933 & 139.938 \\ -8.047 & 1.430 & .925 & 122.533 \\ 10.539 & .561 & .8 .53 & 58.112 \\ -9.238 & 1 ., 492 & .830 & 48.975 \\ -10.046 & 1.520 & .855 & 58.743 \\ 10.986 & .552 & .835 & 50.447 \\ -11.030 & 1.541 & .860 & 61.537 \\ 7.453 & .644 & .942 & 162.872\end{array}$

Orie Amaoji Vs Nkwo Ndoro

Orie Amaoji Vs Ogwumabiri Ibeku

Nkwo Ndoro Vs Ariaria Market

Orie Amaoji Vs Umungasi Market

Nkwo Ndoro Vs Nkwo Ndoro

Nkwo Ndoro Ogwumabiri Ibeku

Nkwo Ndoro Vs Ariaria Market

Ariaria Market Vs Umungasi Market

Ogwumabiri Ibeku Vs Ogwumabiri Ibeku

Ogwumabiri Ibeku Vs Ariaria Market

Ogwumabiri Ibeku Vs Umungasi Market

Ariaria Market Vs Ariaria Market

Ariaria Market Vs Ariaria Market

Umungasi Market Vs Umungasi Market

$R^{2}$ Significant at the $F_{0.01} ; 10=10$

Source: Field survey, 2010

Table 4 shows that in trade relationships between the wholesalers in one market (e.g. Orie Amaorji Market) and farmers in another market (e.g. Ogwumabiri Ibeku Market), the wholesalers use the percentage margin policy bo $\geq \square 0.55 \mathrm{~kg}^{-1}$, in order to determine the wholesale (selling) price of ware yam. But in trade relationships between the wholesalers and farmers in the same market (e.g Eke Agbagwu market), the wholesalers use the fixed margin policy to determine the wholesale (selling) price of their product.

Table 5: Estimated Simple OLS Linear Partial Price Regression and Partial Mark-up Policy of the Ware Yam Retailers in the Farm Gate- Retail, Marketing Channel, in the Study Area.

\begin{tabular}{|c|c|c|c|c|}
\hline \multirow[t]{2}{*}{ Marketing Channel } & \multicolumn{4}{|c|}{ Price Regression $\hat{\mathbf{Y}}_{2 \mathrm{t}}=\hat{\mathbf{a}_{2}}+\hat{\mathbf{b}}_{2} \mathbf{G}_{\mathrm{jt}}+\hat{\mathbf{e}}_{2 \mathrm{i}}$} \\
\hline & $\hat{\mathbf{a}}_{2}$ & $\mathbf{b}_{2}$ & $\mathbf{R}^{2}$ & $\mathbf{F}$ \\
\hline Eke Agbagwu Vs Eke Agbagwu & -5.505 & 1.503 & .979 & 460.997 \\
\hline Eke Agbagwu Vs Orie Amaoji & -3.329 & 1.444 & .935 & 145.009 \\
\hline Eke Agbagwu Vs Nkwo Ndoro & -6.155 & 1.529 & .944 & 167.819 \\
\hline Eke Agbagwu Vs Ogwumabiri Ibeku & -6.961 & 1.543 & .966 & 285.579 \\
\hline Eke Agbagwu Vs Ariaria market & -7.054 & 1.549 & .985 & 636.349 \\
\hline Orie Amaoji Vs Umungasi Markt & -7.111 & 1.554 & .982 & 557.688 \\
\hline Orie Amaoji Vs Orie Amaoji & -5.400 & 1.509 & .955 & 212.808 \\
\hline Orie Amaoji Vs Nkwo Ndoro & -8.991 & 1.592 & .956 & 227.384 \\
\hline Orie Amaoji Vs Ogwumabiri Ibeku & -8.448 & 1.89 & .957 & 222.652 \\
\hline Nkwo Ndoro Vs Ariaria Market & -8.963 & 1.608 & .991 & 1110.384 \\
\hline Orie Amaoji Vs Umungasi Market & -8.948 & 1.611 & .986 & 708.716 \\
\hline
\end{tabular}

Journal of the Faculty of Agriculture and Veterinary Medicine, Imo State University, Owerri www.ajol.info 


$\begin{array}{lllll}\text { Nkwo Ndoro Vs Nkwo Ndoro } & -5.161 & 1.506 & .949 & 187.880 \\ \text { Nkwo Ndoro Vs Ogwumabiri Ibeku } & -5.718 & 1.522 & .963 & 260.027 \\ \text { Nkwo Ndoro Vs Ariaria Market } & -5.914 & 1.531 & .985 & 674.800 \\ \text { Ariaria Market Vs Umungasi Market } & -6.027 & 1.538 & .985 & 678.540 \\ \text { Ogwumabiri Ibeku Vs Ogwumabiri } & -7.029 & 1.556 & .964 & 271.440 \\ \text { Ibeku } & & & & \\ \quad \text { Ogwumabiri Ibeku Vs Ariaria Market } & -7.331 & 1.568 & .991 & 1072.359 \\ \text { Ogwumabiri Ibeku Vs Umungasi } & -7.349 & 1.572 & .987 & 770.715 \\ \text { Market } & & & & \\ \text { Ariaria Market Vs Ariaria Market } & -6.712 & 1.546 & .991 & 1072.359 \\ \text { Ariaria Market Vs Ariaria Market } & -7.036 & 1.560 & .983 & 566.933 \\ \text { Umungasi market Vs Umungasi } & -6.431 & 1.542 & .982 & 533.878 \\ \text { Market } & & & & \end{array}$

$\mathbf{R}^{2}$ Significant at the $\mathbf{F}_{0.01} ; 10=10$

Source: Field survey, 2010

In trade relationships (Table5) between the retailers in one market (e.g Eke Agbagwu market) and farmers in another market (e.g Orie Amaoji market), and between the retailers and farmers in the same market (e.g Eke Agbagwu market), the retailers adopt the percentage margin policy $b_{2} \geq$ $\square 1.50 \mathrm{~kg}^{-} 1$, in order to determine the retail (selling) price of their product.

Table 6: Estimated Simple OLS Linear Partial Price Regression and Partial Mark-up Policy of the Ware Yam Retailers in the Wholesale-Retail Marketing Channel in the Study Area.

\section{Marketing Channel}

Eke Agbagwu Vs Eke Agbagwu

Eke Agbagwu Vs Orie Amaoji

Eke Agbagwu Vs Nkwo Ndoro

Eke Agbagwu Vs Ogwumabiri Ibeku

Eke Agbagwu Vs Ariaria market

Orie Amaoji Vs Umungasi Market

Orie Amaoji Vs Orie Amaoji

Orie Amaoji Vs Nkwo Ndoro

Orie Amaoji Vs Ogwumabiri Ibeku

Nkwo Ndoro Vs Ariaria Market

Orie Amaoji Vs Umungasi Market

Nkwo Ndoro Vs Nkwo Ndoro

Nkwo Ndoro Vs Ogwumabiri Ibeku

\begin{tabular}{llll}
\multicolumn{1}{c}{$\hat{\mathbf{a}}_{\mathbf{1}}$} & $\mathbf{b}_{\mathbf{1}}$ & $\mathbf{R}^{\mathbf{2}}$ & \multicolumn{1}{c}{$\mathbf{F}$} \\
4.399 & 1.019 & .934 & 140.778 \\
4.406 & 1.016 & .893 & 83.243 \\
4.484 & 1.012 & .922 & 188.136 \\
8.888 & 876 & .844 & 54.218 \\
9.482 & 868 & .845 & 54.723 \\
4.251 & 1.007 & .936 & 146.420 \\
3.251 & 1.046 & .885 & 76.635 \\
3.234 & 1.045 & .918 & 111.909 \\
7.680 & .907 & .845 & 54.703 \\
8.133 & .902 & .855 & 58.730 \\
2.806 & 1.044 & .91 & 158.623 \\
5.370 & 1.004 & .929 & 130.198 \\
10.172 & .858 & .829 & 48.444 \\
\hline
\end{tabular}

Journal of the Faculty of Agriculture and Veterinary Medicine, Imo State University, Owerri www.ajol.info 


\begin{tabular}{lllll}
\hline Nkwo Ndoro Vs Ariaria Market & 10.726 & .850 & .832 & 49.498 \\
Ariaria Market Vs Umungasi Market & 5.388 & .992 & .931 & 134.360 \\
Ogwumabiri Ibeku Vs Ogwumabiri & 8.990 & .882 & .841 & 52.938 \\
Ibeku & & & & \\
Ogwumabiri Ibeku Vs Ariaria Market & 9.584 & .874 & .843 & 53.504 \\
Ogwumabiri Ibeku Vs Umungasi & 4.092 & 1.020 & .938 & 166.449 \\
Market & & & & \\
Ariaria Market Vs Ariaria Market & 10.252 & .855 & .828 & 48.173 \\
Ariaria Market Vs Ariaria Market & 4.527 & 1.007 & .929 & 130.555 \\
Umungasi market Vs Umungasi & 4.876 & .998 & .934 & 140.675 \\
Market & & & & \\
\hline
\end{tabular}

\section{$\mathbf{R}^{2}$ Significant at the $\mathbf{F}_{0.01}, 10=10$}

Source: Field survey, 2010

But in trade relationships (Table 6) between the retailers in one market (e.g Eke Agbagwu market) and wholesalers in another market (e.g Nkwo Ndoro market), and between the retailers and wholesalers in the same market (e.g Ariaria market), the retailers adopt the fixed margin policy $b_{1}$ $\geq \square 0.85 \mathrm{~kg}^{-1}$, in order to determine the retail (selling) price of their product. The price regression results (Tables 4, 5 and 6) show significant relationships between the marketing margins and the mark-up policies of the traders in the study area, because the coefficient of determination $\mathrm{R}^{2}$, $\mathrm{s}$ is of the inter-market prices of ware yam are significant at the $\mathrm{F}_{0.01}$ level, and these led to the rejection of the null hypothesis of the study.

The price regression results (table 4, 5 and 6) also indicate that the traders (wholesalers and retailers) determine the selling price of ware yam by using either the fixed or percentage margin policy to reflect the costs of the utilities of place, time and possession, created in the traded ware yam, as a result of the marketing functions carried out by the traders in the transfer of the commodity from the farmers to consumer in the study area. The percentage margin policy is the marketing strategy used by the traders to determine the selling price of ware yam by increasing its supply price by a certain percentage of the naira amount. On the other hand, the fixed margin policy is the marketing strategy used by the traders to determine the selling price of ware yam by increasing its supply price by a certain fixed naira amount.

The mark-up policies on ware yam (Tables 4, 5 and 6) indicate that the traders in the study area generally enline with the reports of Olukosi and Isitor (1990); Kohls and Uhl (1990); Downey and Erickson (1981), in relation to increase in marketing margins and the number and cost of the utility-creating marketing functions performed by the traders in the food marketing system. However, the traders are not exploitative in terms of excess marketing margins (Reddy et al 2006). Rather the marketing margins are determined by the number of traders and paid marketing functions in the marketing chain. A division of labour between the traders resulting in greater specialization may increase the efficiency of marketing, so also, increased competition resulting from a greater number of participants (Scarborough and Kydd 1992)

Journal of the Faculty of Agriculture and Veterinary Medicine, Imo State University, Owerri www.ajol.info 


\section{Conclusion and Policy Implication of Findings}

The marketing of ware yam in the study area was characterized by a semi-decentralized marketing channel, and marketing margin and mark-up policy on trade that are highly significantly related. The semi-decentralized marketing channel enabled utilities to be created in the marketed farm product through the marketing functions carried out by the traders. The marketing margin and mark-up policy of the traders were aimed at maximum consumer satisfaction and farmer share relative to the marketing share per unit of the consumer expenditure on ware yam in the study area. The findings from the study reflect the conditions of perfect competition (Koutsoyannis, 2003) in food trade in developing economies, and are therefore, implicated for improving the levels of employment, output, consumption, better income distribution and poverty reduction in the study area.

\section{References}

Abia State of Nigeria Civil Service Commission Annual Report (1977). In: Official Document NO. 4 of 1998. Printed by the Government Printer Umuahia.

Adekanye, T.O. and Olayide, S.O. (1988). "Definition of terms". In: Readings in agricultural marketing, Adekanye (ed) Longman Nigeria, pp.4-11.

Agboola, S. A. (1a 7a). An agricultural atlas of Nigeria Oxford University Press, pp 29-52.

Allen, G.R. (1959). "Short-term variations in retailing margins on fruits and vegetables in east Pakistan”. Farm Economist, 2(6).

Anuebunwa, F. O.2002. A structural analysis of yam trade flows into Abia State of Nigeria. Nigerian Agriculture Journal 33: 17-22.

Asumugha, G.N., M.E. Njoku, B.C. Okoye, O.C. Aniedu, M.C. Ogbonna, H.C. Anyaegbunam, O.A. Akinkpule, O. Ibeagi and A. Amaefula (2009). 'An analysis of the supply of seed yam in Nigeria'. African Journal of Business Management Vol. 3 (1), Pp 28-31

Asumugha, G.N., O.C. Aniedu, M.C. Ogbonna, B.C. Okoye, O.A. Akinpelu, H.N. Anyaegbunam, J.E.G. Ikeorgu, G.C. Orkwor, K.I. Nwosu, and M.C. Okwusi 2005. Comparative economic analysis of seed yam production techniques in Nigeria. Annual Report 2005, National Root Crops Research Institute, Umudike, Nigeria.

Downey, W. D. and Erickson, S.P. (1981). Agribusiness Management McGraw-Hill Inc. $2^{\text {nd }}$ Edition. Pp 246-248.

Ejiga, N. O. O (1977) Economic analysis of storage, distribution and consumption of cowpea in northern nigeria. Unpublished $\mathrm{PhD}$ thesis, Cornell University. In: Readings in Agricultural marketing, Adekanye, T. O. (ed) Pp 157-1

Eluagu, L.S., M.O. Ijere, O.Okereke, and F.I. Nweke. 1990. Inter state trade on yams in southeastern Nigeria. Nigeria Journal of Agricultural Science 5(1): 187-214.

Journal of the Faculty of Agriculture and Veterinary Medicine, Imo State University, Owerri www.ajol.info 
FAO. (2006). Food and Agricultural Organization Database.

Hays, H.M. (Jnr). (1975). "The marketing and storage of food grain in Northern Nigeria'. Zaria 1975. Inc. Olukosi, J.O. and Isitor, S.U. (1990). Introduction to Agricultural Marketing and prices: principles and applications. Living Books Series, G. U. Publication, Abuja FCT, P. 20.

Iheke, O.R. and I.O. Obasi (2009) Household energy needs: An Economic Analysis of fuel wood marketing in umuahia metropolis of Abia State Nigeria, Proceedings of the $43^{\text {rd }}$ Annual Conference of the agricultural society of Nigeria (ASN). $20^{\text {th }}-23^{\text {rd }}$ october 2009 , Abuja. Pp 308311

Kohls, R. L.and Uhl, J.W. (1990). Marketing of Agricultural Products. Mac Ian publishing Co. New York. $7^{\text {th }}$ edition. Pp. 18-21-185-186.

Kotler, P. (1997). Marketing Management: Analysis, planning, implementation and control. International, Inc. $9^{\text {th }}$ Edition

Koutsoyiannis, A. (2003). Modern Microeconometric. $2^{\text {nd }}$ edition. Pp 154-155.

Manyong, V.M., R. Asiedu, and G.O. Olaniyan, 2001. Farmers' perception of and actions on resource management constraints in the yam based systems of western Nigeria. Pages 156-167 in Root crops in the 21 st century, edited by M.O. Akoroda and J.M. Ngeve, Proceedings of 7th Triennial Symposium ISTRC-AB, 11-17 October 1998, Cotonou, Benin Republic.

Nigerian National Bureau of Statistics (2006). Nigerian National Bureau Data Base http://www.nigerianstat.gov.ng

Olukosi, J.O. and Isitor, S.U. ( 1990). Introduction to agricultural marketing and prices: Principles and applications. Living Books Series, G.U. Publications, Abuja, FCT. Pp 1-2,8-15, 20,40-43.

Reddy, S. S., Ram, P. R., Sastry, T. V. N., Devi, I. B. (2006) Agricultural Economics. Oxford and IBH publishing co. PVT ltd. New Delhi. P526.

Scarborough, V. and Kydd, J.(1992) Economic Analysis of Agricultural Markets: A manual. Chatham, U.K: Natural Resources Institute. P77.

Shepherd, A.W. 2000. Understanding and using market information. Marketing Extension Guide No.2. FAO, Rome. 85 pp.

Stanton, W.J. (1983). Fundamentals of Marketing. McGraw-Hill Inc., $6^{\text {th }}$ Edition. Pp 283284,447 . 